\title{
Econometric Analysis of Dynamics of Personnel Training in Tourism Sphere
}

\author{
Anar Eminov', Anar Mirzayev², Ilaha Aliyeva ${ }^{3}$ Nazim Hajiyev $^{4,5^{*}}$ \\ ${ }^{1}$ Head of Career and communication department, Azerbaijan Tourism and Management University, \\ a.eminov@atmu.edu.az \\ ${ }^{2}$ Dean of Business Administrationt, Azerbaijan Tourism and Management University, a.mirzayev@atmu.edu.az \\ ${ }^{3}$ Deputy director of Business Adminstration, Azerbaijan Tourism and Management University, \\ i.aliyeva@atmu.edu.az \\ ${ }^{4}$ Dr., Department of Economics and Business management at UNEC Business School, Azerbaijan State \\ University of Economics (UNEC), ${ }^{5}$ Visiting Scholar, Davis Center for Russian and Eurasian Studies, Harvard \\ University, n.hajiyev@unec.edu.az
}

Article History: Received: 10 November 2020; Revised 12 January 2021; Accepted: 27 January 2021; Published online: 5 April 2021

\begin{abstract}
According to the statistical data of recent years, tourism has been one of the ever-growing sectors in Azerbaijan. Thus, in the last five years, there has been a steady increase in the number of entrepreneurship subjects serving tourism in Azerbaijan and the number of foreign nationals traveling for tourism, correspondingly 4.5 and 8.5 percent. At present, the direct share of the tourism industry in the country's GDP and employment is 4.5 and 3.3 percent, respectively. In the article econometric analysis of the dependence on the relationship between tourism industry graduates and their development has been done. The regression equation of the dependence of the number of graduates studying tourism on the number of tourists in the country and the dependence of the tourism sector's GDP on the number of graduates in the tourism sector were estimated using the Eviews software based on 2008-2017 statistical data using the least squares method.
\end{abstract}

Keywords

tourism, econometric model, personnel potential, GDP, tourism education

\section{Introduction}

The personnel potential of the tourism sector is organized and managed in accordance with its production program. Thus, the total volume of services and its performance is determined by the total workforce of each person. Training of personnel is formed in the educational system. Their use specializes in a specific touristic facility (Alirzayev, 2011). Classification of tourism is scientific and practical issue. It plays a role in understanding the essence of the world's tourism exchange and setting up knowledge. Changes in the volume and quality of tourist services, the emergence of new types and forms of tourism activities are always in the process of improvement and can not be considered a finished process. Accordingly, personnel improvement in this area is always actual (Kasumov R.M., 2012).

Azerbaijan is very popular with oil and gas resources. İn the articles of Birdsall N., Pinckney T., Sabot R. (2001); Blanco L., Grier R. (2010); Corden W. M., Neary J. P. (1982); Davis G. (1995); Engerman S., Sokoloff K. (2002); Gylfason T. (2001); Gylfason T. (2008) use and exploitation of natural resources in some countries have been studied. Yadulla Hasanli, Nazim Hajiyev, Fail Kazimov (2019): Yadulla Hasanli, Simrah Ismayilova (2017). A number 
of investigations have been carried out in this regard in the case of |Azerbaijan in the articles of Gorkhmaz Imanov, Yadulla Hasanli (2014).

The geographical location, natural and climatic conditions and rich historical monuments of Azerbaijan show that the development of the tourism sector is favorable. The development of the non-oil sector, including tourism, is a topical problem, with the use of oil revenues to ensure the country's sustainable development.

Julius Arnegger, Marc Florian Herz (2015), explored the impact of tourism on economic and cultural development of Azerbaijan based on the input-output model. Yadulla Hasanli, Sailau Baizakov, Sudabe Salihova (2019) published a comparative analysis of the influence of investment in tourism on the economic development indicators of these countries, using the INPUT-OUTPUT MODEL OF AZERBAIJAN, KAZAKHSTAN AND IRAN which is rich with oil and gas reserves.

\section{Method}

During the research, research methods like systematic approach, logical summarization, econometric modeling, statistical analysis, mathematical-economic modeling were used The research database is compiled by the State Statistical Committee of the Republic of Azerbaijan, the Ministry of Education and its annual reports and indicators.

\section{Findings}

As noted already, tourism is not only limited to presenting the country's cultural, historical and natural resources to the country's visitors, but also the economic activity. From this point of view, opening up a few questions from the perspective of the research would increase the harmony of the research. These questions are mainly related to the impact of each tourist coming to the country on tourism personnel training and the impact of tourism personnel training on the gross domestic product of country. In this regard, the database provided in Table 1 will be used.

Table 1. Number of graduates who have studied tourism specialty during 2008-2017

\begin{tabular}{|c|c|c|c|c|c|c|}
\hline 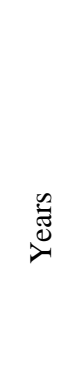 & 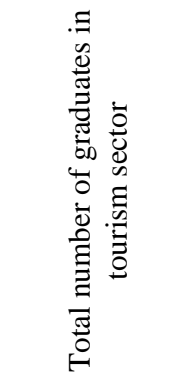 & 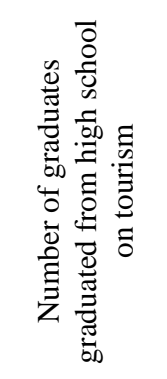 & 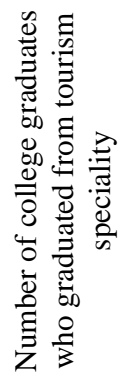 & 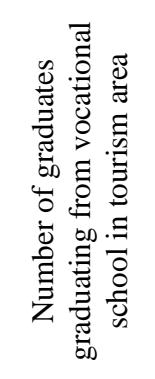 & 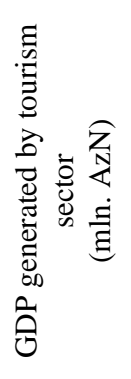 & 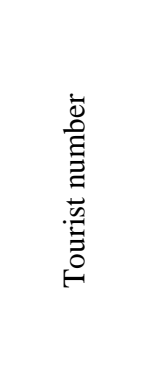 \\
\hline & TGTS & High scholl & College & Vocational & GDP & $\mathrm{TN}$ \\
\hline $1^{*}$ & $2^{*}=3^{*}+4^{*}+5^{*}$ & $3^{*}$ & $4^{*}$ & $5^{*}$ & $6^{*}$ & $7^{*}$ \\
\hline 2008 & 47 & 47 & 0 & 0 & 560,2 & 1898939 \\
\hline 2009 & 42 & 42 & 0 & 0 & 719,5 & 1830367 \\
\hline 2010 & 232 & 154 & 78 & 0 & 881,5 & 1962906 \\
\hline 2011 & 327 & 176 & 83 & 68 & 1300 & 2239141 \\
\hline 2012 & 441 & 211 & 85 & 145 & 1549,6 & 2484048 \\
\hline 2013 & 535 & 256 & 101 & 178 & 1828,4 & 2508904 \\
\hline 2014 & 756 & 309 & 176 & 271 & 2106,6 & 2297804 \\
\hline 2015 & 795 & 312 & 208 & 275 & 2362,2 & 2006176 \\
\hline 2016 & 861 & 344 & 219 & 298 & 2746,1 & 2248773 \\
\hline 2017 & 869 & 349 & 208 & 312 & 3151,0 & 2696745 \\
\hline
\end{tabular}


As can be seen from the table, the integration of specialized tourism personnel into the labor market has been rising at an increasing pace since 2008. Undoubtedly, this is not a coincidence. Thus, starting from 2006, Azerbaijan has begun to allocate a special place in the field of tourism for its strategic development goals. Azerbaijan has the potential to attract a large number of international tourists. Tourism is increasingly becoming an important part of Azerbaijan's economy. In Azerbaijan, 2011 has been declared the "Year of Tourism." Today works are carried out to draw tourists from foreign countries. In addition, works are carried out to promote tourism opportunities of Azerbaijan abroad. Tourism is increasingly becoming an important part of Azerbaijan's economy. Tourism receipts account for $8.4 \%$ of the country's GDP and has the potential to contribute further to the non-oil diversification of the economy. The boom in the country's oil and gas industries has given a boost to the development of the tourism sector creating a demand for more and improved accommodation facilities, infrastructure and services. As Azerbaijan is establishing itself on the international arena, the country regularly hosts regional and international events and international exhibitions. The number of hotel establishments currently operational in Azerbaijan has increased from 320 in 2007 up to 527 in 2014, including such world famous brands as Hilton, Marriott, Four Seasons, Kempinski, Jumeirah and Fairmont (Azerbaijan Statistic Commitee, 2015).

The successful oil strategy shows itself on non-oil sector in fast-growing Azerbaijan Republic. Tourism industry is one of the important fields of non-oil sector. Due to the potential of increasing incomes to the state budget, Azerbaijan Government targeted to develop tourism industry and make it the most sustainable and competitive part of the economy. Azerbaijan Republic is one of the countries with huge potential of tourism resources. Both natural geographic location and the position in the modern world made our country more interesting place for tourists. It is more important having professional and qualitative human resources for increasing the number of tourists coming to us. According to experts, the demand to tourism personnel will be more than 75000, until 2023. But now, professional cadre shortage on tourism is one of the main problems, preventing the development of perspective tourism industry of our country

Diagram 1. The number of students graduating in tourism in Azerbaijan

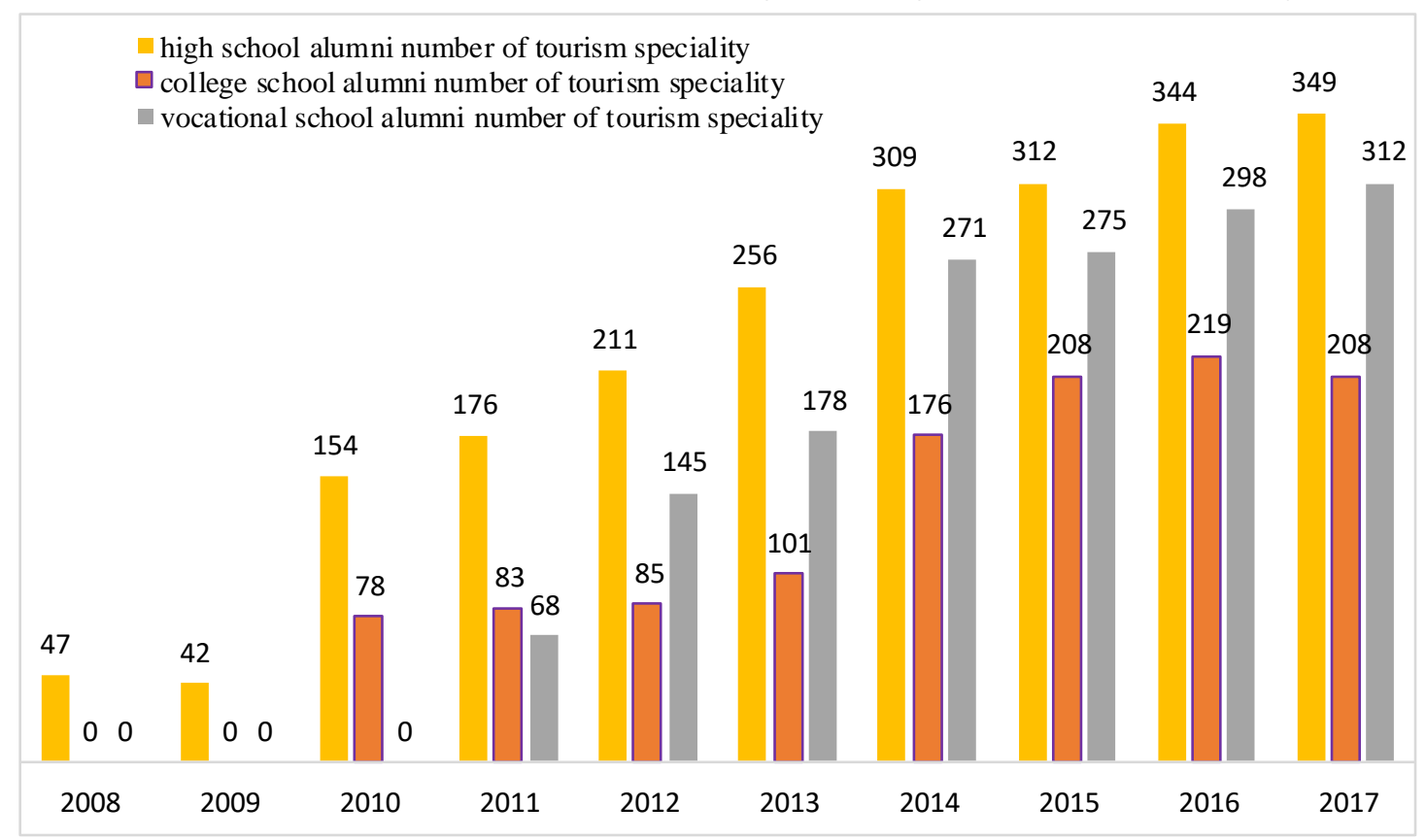


As you can see from the diagram, the number of students graduating in tourism has increased year by year and reached the highest level in 2017 .

Now let's apply the economic mathematical modeling capabilities based on the given data and determine the forecasting models. Let's first of all highlight the impact every tourist who travels to the country on tourism personnel training. For this purpose, econometric models of mutual interaction have been studied in the following forms:

$$
\operatorname{LOG}(\mathrm{TGTS})=\mathrm{C}(1)+\mathrm{C}(2) * \mathrm{LOG}(\mathrm{NA})+\mathrm{u}
$$

Here, the TGTS is the number of graduates studying tourism, the NA is the number of tourists coming to the country, and $\mathrm{u}$ is a random departure. $\mathrm{C}$ (1) and $\mathrm{C}$ (2) are the parameters of the model. (1) Finding parameters of the regression equations and checking the adequacy of the obtained models was made by the Eviews Applied Software Package with econometric modeling methods.

The regression equation of the semiconductor trend model (2) of the number of graduates studying tourism has been estimated econometrically based on the data in the table. The result of the Eviews system was as follows:

$$
\begin{array}{lcc}
\text { LOG(TGTS) }=-32.11+ & 2.64 * \operatorname{LOG}(\mathrm{NA}(-4))(2) \\
\text { s.s. } & (1,49) & (0,06) \\
\text { t-test: } & (3.78) & (4.53) \\
\text { prob. } \quad(0.01) & (0.00) \\
\text { R }=0,80 ; & \mathrm{R}^{2 *}=0,77 ; \quad \mathrm{DW}=1,6
\end{array}
$$

The model's statistical characteristics and relevant tests show that the model is adequate. (see Appendix 1) So, the standard errors of the parameters are considerably smaller than the estimate found by the smallest squares method. The determinant coefficient (R2) and the modified determinant coefficient estimate $(\mathrm{R} 2 *)$ are closer, and the F-statistic estimate is satisfactory, indicating that the determinant coefficient is significant. $\mathrm{R} 2=0.80$ indicates that number people who is coming with tourism purpose to the country change graduates studying tourism (TGTS) $80 \%$ is explained. The remaining $20 \%$ of the change occurred at the expense of other factors that were not considered. Durbin-Watson statistics is 1.6 ( 2 is the ideal option), indicating that the remainder of the model is not the 1st compact autocorrelation. This shows that the model is also important for forecasting.

(2) suggests that the $1 \%$ increase in the number of tourists coming to the country to increase the quality of the personnel working in the tourism sector increases the number of graduates in the tourism sector by $2.64 \%$ four years later.

Now, another aspect of the research is to determine the economic effectiveness of the number of graduates studying in tourism. To do this we need to determine the impact of graduates studying tourism on the gross domestic product in tourism. For this purpose, econometric models of mutual interaction have been studied in the following forms:

$\mathrm{LOG}\left(\mathrm{T} \_\mathrm{GDP}\right)=\mathrm{C}(1)+\mathrm{C}(2) * \mathrm{LOG}(\mathrm{TGTS})+\mathrm{u}(3)$ 
Here, the TGTS is the number of graduates studying tourism, T_GDP - the gross domestic product generated in the tourism sector, and $u$ - random departures. $C$ (1) and $C$ (2) are the parameters of the model. (1) Finding parameters of the regression equations and checking the adequacy of the models obtained was made by the Eviews Applied Software Package with econometric modeling methods.

The regression equation of the gross domestic product of the semiconductor trend model (4) generated in the tourism industry is estimated econometrically based on the data in the table. The result of the Eviews system was as follows:

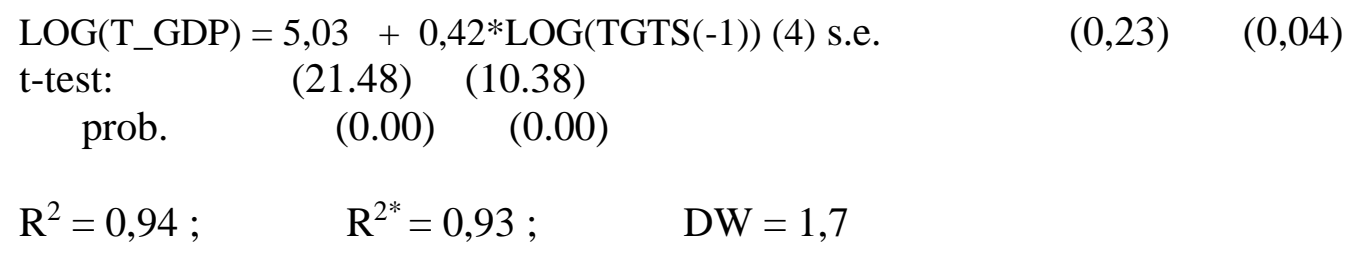

(4) the model's statistical characteristics and relevant tests indicate that the model is adequate. (see Appendix 2) So, the standard errors of the parameters are much smaller than the smallest squares method. The determinant coefficient (R2) and the modified determinant coefficient estimate $(\mathrm{R} 2 *)$ are close, and the F-statistic estimate is satisfactory, indicating that the determinant coefficient is significant. R2 $=0.94$ indicates that $94 \%$ of the total number of graduates in the tourism industry (TGTS) changes in the Gross Domestic Product (GDP) in the tourism sector. The remaining $6 \%$ of the change occurred at the expense of other factors that were not considered. Durbin-Watson statistics is 1.7 ( 2 is desirable), indicating that the remainder of the model is not the 1st compact autocorrect. This shows that the model is also important for forecasting.

\section{Results, Conclusions and Recommendations}

The beautiful nature of Azerbaijan, hospitality of its people, the country's capital with its super modern and ancient buildings draws the attention of all tourists visiting this South Caucasian country. In recent years, the creation of a diversified tourism infrastructure in Azerbaijan has increased the interest of foreign tourists to the country.

There are many opportunities for tourism in our country, including rural, health, environmental, cultural, social, commercial, sport and etc. Simplification of visa regime also plays a major role in the development of tourism in Azerbaijan. Currently, citizens of a number of countries get visas right at the Azerbaijani airports, while other tourists can visit the country by getting online tourist visas.

Model (2) shows that the $1 \%$ increase in the number of tourists coming to the country to increase the quality of the personnel working in the tourism sector increases the number of graduates in the tourism sector by $2.64 \%$ four years later.

Model (4) shows that the $1 \%$ increase in the number of students and graduates in tourism increases the tourism GDP by $0.42 \%$ in order to increase the quality of the cadres working in tourism. 


\section{References}

[1] Alirzayev A.K., (2011), Economy and management of tourism. Baku: Publishing House of Economic University.

[2] Andriotis, K., \& Vaughan, D.R. (2004). The tourism workforce and policy: Exploring the assumptions using Crete as the case study. Current Issues in Tourism, 7 (1), 66-87.

[3] Birdsall N., Pinckney T., Sabot R. (2001). Natural Resources, Human Capital, and Growth // Resource Abundance and Economic Growth / R. M. Auty (ed.). Oxford: Oxford University Press, P. 57—75.

[4] Blanco L., Grier R. (2010). The (Non) Effect of Natural Resource Dependence on Human and Physical Capital in Latin America. Mimeo.

[5] Brooks, C., (2002), Introductory Econometrics for Finance, Cambridge University Press.

[6] Bruff C., Dean., A. \& Nolan J. (2005). Student perceptions of the educational quality provided by different delivery modes. 2nd Asia-Pacific Educational Integrity Conference, University of Newcastle: Australia.

[7] Corden W. M., Neary J. P. (1982). Booming Sector and De-Industrialization in a Small Open Economy // The Economic Journal. Vol. 92, No 368. P. 825 - 848.

[8] Davis G. (1995). Learning to Love the Dutch Disease: Evidence from the Mineral Economies // World development. Vol. 23, No 10. P. $1765-1779$.

[9] Engerman S., Sokoloff K. (2002). Factor Endowments, Inequality and Paths of Development among New World // NBER Working Paper. No 9259.

[10] Imanov Gorkhmaz, Hasanli Yadulla (2014). Forecasting of oil and gas extraction in Azerbaijan on the basis of Hubbert's model. The jurnal of economic sciences: Theory and practice, pp.40-52, Volume 71, \#1/2014, ISSN 2220-8739.

[11] Gylfason T. (2001). Natural Resources, Education, and Economic Development // European Economic Review.. Vol. 45, No 4 - 6. P. 847-859.

[12] Gylfason T. (2008). Development and Growth in Mineral-Rich Countries // CEPR Discussion Paper. No 7031.

[13] Gee, C.Y. (2002). Tourism Employment Issues: The PATA Viewpoint. In: WTO. Human Resources in Tourism: Towards a new paradigm. (pp. 71-77). Madrid: OMT.

[14] Hasanli Yadulla, Baizakov Sailau, Salihova Sudabe (2019). ASSESSMENT OF THE IMPACT OF TOURISM SECTOR ON THE ECONOMY OF AZERBAIJAN, KAZAKHSTAN AND IRAN USING INPUT-OUTPUT MODELS. 37th International Scientific Conference on Economic and Social Development - "Socio Economic Problems of Sustainable Development". pp.671-681.

[15] Hasanli Yadulla, Hajiyev Nazim, Kazimov Fail (2019). The Impact of Natural Resource Exploitation on Balanced Development with Modified Reproduction Scheme Based on Supply Chain Management. International Journal of Supply Chain Management, Vol. 8, No. 1, February. pp.438-443.

[16] Hasanli Yadulla, Ismayilova Simrah (2017). Econometric model of dependence between oil prices and the world's external debt level and oil production. Economic Annals-XXI, 166(7-8), p.11-15.

[17] Kasumov R.M., 2012, International tourism market, Monograph, Baku: Publishing House of Economic University

[18] Julius Arnegger, Marc Florian Herz (2015). Economic and destination image impacts of mega-events in emerging tourist destinations. Journal of Destination Marketing \& Management. 5(2).

[19] Mammadov J.A., Balalov B., (2014). Visiting tourism and ways of its development in Azerbaijan, Baku: Publishing House of Muterijim

[20] Witt, S. F., Song, H., Louvieris, P., (2003). "Statistical testing in forecasting model selection", Journal of Travel Research 42, p.151-158.

[21] Witt, S. F., Song, H., Wanhill, S., (2004). "Forecasting Tourism Generated Employment", Tourism Economics (forthcoming) 


\section{Appendix 1}

Table A1.1. Main statistical characteristics of the Model (2) and appropriate adequacy tests

\begin{tabular}{|c|c|c|c|c|}
\hline Variable & Coefficient & Std. Error & t-Statistic & Prob. \\
\hline $\mathrm{C}$ & -32.10824 & 8.499942 & -3.777466 & 0.0129 \\
\hline LOG(NA(-4)) & 2.642113 & 0.582758 & 4.533810 & 0.0062 \\
\hline R-squared & 0.804347 & Mean dependent var & & 6.427585 \\
\hline Adjusted R-squared & 0.765216 & S.D. dependent var & & 0.380794 \\
\hline S.E. of regression & 0.184512 & Akaike info criterion & & -0.307248 \\
\hline Sum squared resid & 0.170223 & Schwarz criterion & & -0.322703 \\
\hline Log likelihood & 3.075370 & Hannan-Quinn criter. & & -0.498260 \\
\hline F-statistic & 20.55543 & Durbin-Watson stat & & 1.576824 \\
\hline Prob(F-statistic) & 0.006204 & & & \\
\hline \multicolumn{5}{|c|}{ Heteroskedasticity Test: Breusch-Pagan-Godfrey } \\
\hline F-statistic & 0.931068 & Prob. $F(1,5)$ & & 0.3789 \\
\hline Obs*R-squared & 1.098871 & Prob. Chi-Square(1) & & 0.2945 \\
\hline Scaled explained SS & 0.358115 & Prob. Chi-Square(1) & & 0.5496 \\
\hline
\end{tabular}

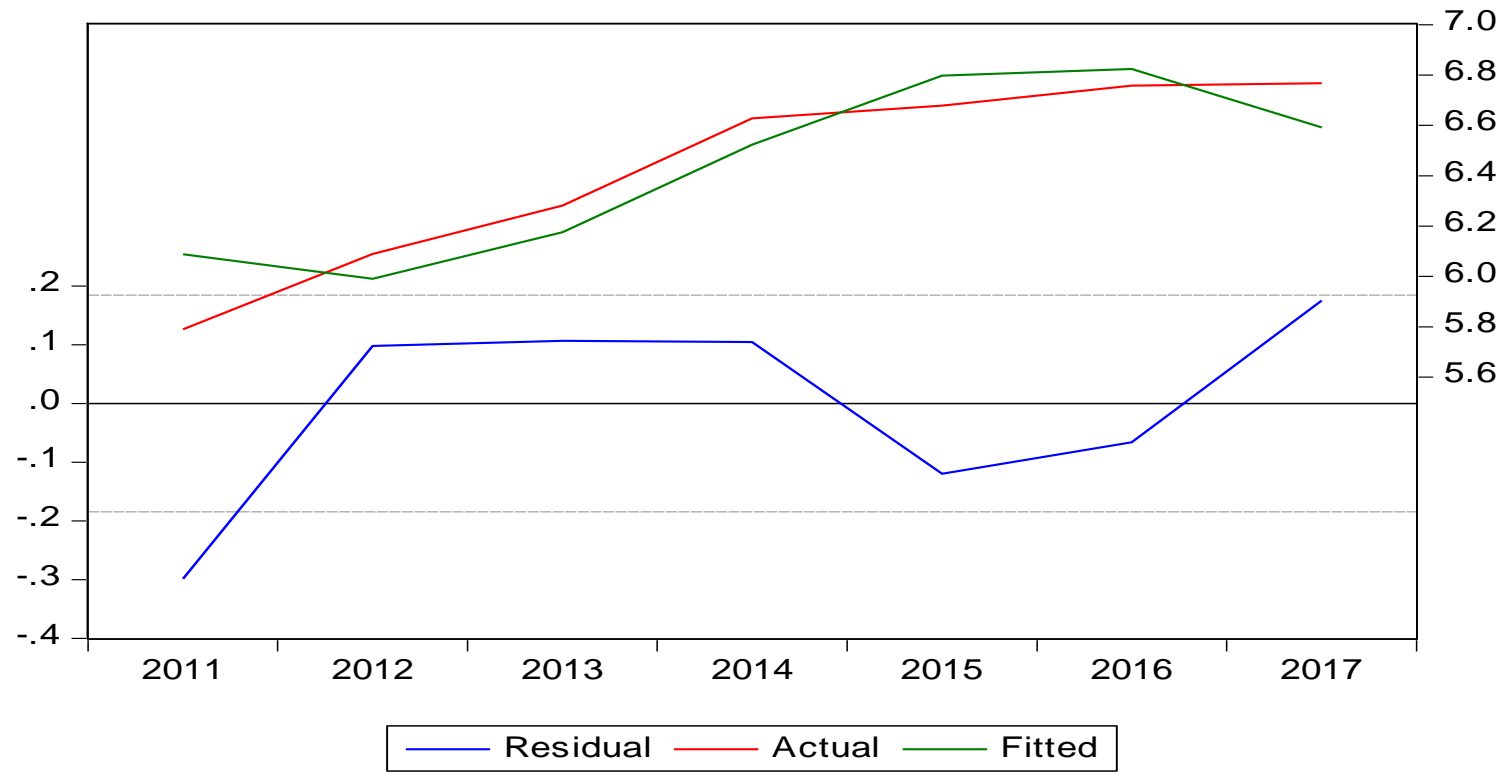




\section{Appendix 2}

Table A1.2. Main statistical characteristics of the model (4) and appropriate adequacy tests

\begin{tabular}{|c|c|c|c|c|}
\hline Variable & Coefficient & Std. Error & $\mathrm{t}$-Statistic & Prob. \\
\hline $\mathrm{C}$ & 5.031068 & 0.234255 & 21.47685 & 0.0000 \\
\hline LOG(TGTS(-1)) & 0.419452 & 0.040391 & 10.38484 & 0.0000 \\
\hline $\begin{array}{l}\text { R-squared } \\
\text { Adjusted R-squared }\end{array}$ & $\begin{array}{l}0.939048 \\
0.930341\end{array}$ & $\begin{array}{l}\text { Mean dependent var } \\
\text { S.D. dependent var }\end{array}$ & & $\begin{array}{l}7.420093 \\
0.502301\end{array}$ \\
\hline $\begin{array}{l}\text { S.E. of regression } \\
\text { Sum squared resid } \\
\text { Log likelihood }\end{array}$ & $\begin{array}{l}0.132572 \\
0.123028 \\
6.546101\end{array}$ & $\begin{array}{l}\text { Akaike info criterion } \\
\text { Schwarz criterion } \\
\text { Hannan-Quinn criter. }\end{array}$ & & $\begin{array}{l}-1.010245 \\
-0.966417 \\
-1.104825\end{array}$ \\
\hline F-statistic & 107.8448 & Durbin-Watson stat & & 1.668407 \\
\hline Prob(F-statistic) & 0.000017 & & & \\
\hline \multicolumn{5}{|c|}{ Heteroskedasticity Test: Breusch-Pagan-Godfrey } \\
\hline F-statistic & 0.378677 & Prob. F(1,7) & & 0.5578 \\
\hline Obs*R-squared & 0.461884 & Prob. Chi-Square(1) & & 0.4967 \\
\hline Scaled explained SS & 0.120922 & Prob. Chi-Square(1) & & 0.7280 \\
\hline
\end{tabular}

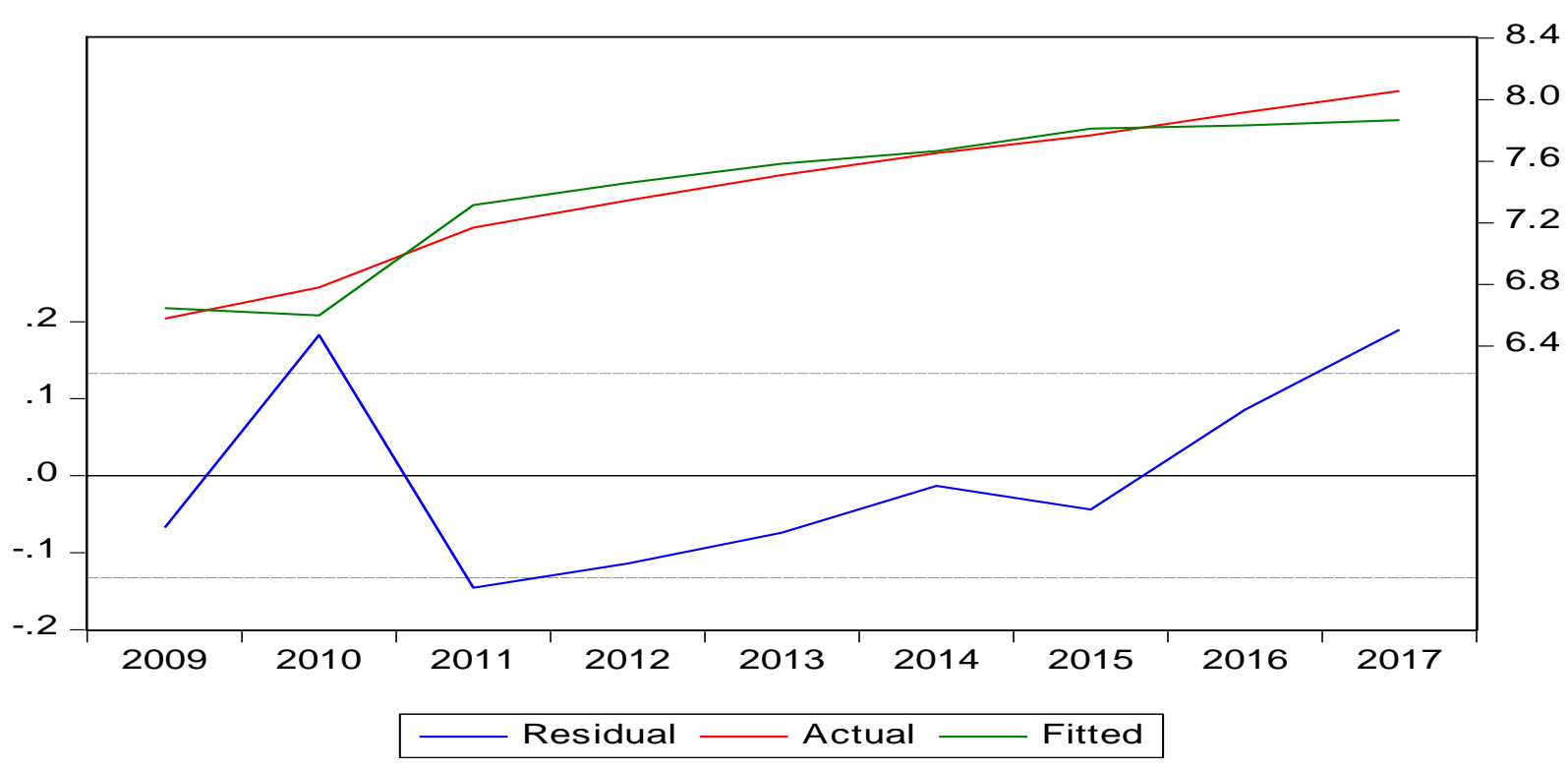

